Insight Botany 2 (2): 7-11, 2012

ISSN 2044-8767 / DOI: 10.5567/BOTANY-IK.2012.7.11

(C) 2012 Insight Knowledge, UK

\title{
Breaking of Seed Dormancy in Prangos pabularia and Prangos uloptera Growing in Iran
}

\author{
Seyed Mehdi Razavi \\ Department of Biology, Faculty of Sciences, University of Mohaghegh Ardabili, Ardabili, Iran
}

\begin{abstract}
Background: The Prangos genus (Apiaceae) comprised of 30 species distributed from East Europe to China. In this study we study the seed dormancy breaking and germination of $P$. pabularia and $P$. uloptera that are most widespread species of the genus. In order to break the seed dormancy the following treatments, after seeds sterilizing, were performed: different temperatures, scarification, cold stratification, warm stratification, alternating low temperatures, $\mathrm{GA}_{3}$ and light/darkness. After any treatment, germination percentage and rate were measured. On the other hand, the seeds embryos were excised and its length and morphology were studied. Results and Conclusion: The results of this study showed that seeds of studied plants have a deep dormancy that can be broken only by cold stratification. Optimal germination temperature was $5^{\circ} \mathrm{C}$ for P. pabularia and $10^{\circ} \mathrm{C}$ for $P$. uloptera. $\mathrm{GA}_{3}$ could not substitute for cold stratification in dormancy breaking. Our finding also revealed that the seeds have undeveloped embryos (3-3.5 $\mathrm{mm}$ in length) at seed dispersal time growing approximately to $8 \mathrm{~mm}$ during cold stratification. Thus, it could be concluded that seed dormancy in the both Prangos species is deep, complex and morphophysiological which should be eliminated by a long period of chilling.
\end{abstract}

Key words: Prangos pabularia, Prangos uloptera, seed germination, cold stratification, morphophysiological dormancy

\section{INTRODUCTION}

Prangos Lindl is a perennial genus of the Apiaceae represented by 30 species in the world. Prangos species are widely used in folk medicine as tonic, anti flatulent, anti hemorrhoids and for treatment of intestinal worms and digestive disorders (Dokoric et al., 2004) and treatment of leukoplakia (Shikishima et al., 2001). Prangos pabularia Lindl and Prangos uloptera DC. are the most widespread species of the genus that are distributed from East Europe to central and Eastern Asia (Rechinger and Hedge, 1987).

Prangos pabularia has been used in Iran as medicinal plant under common names of Djashir ulofeii and Badiane-Kohi. In traditional medicine, extracts of the roots and fruits of the plant has been used for treatment of digestive disorders, healing scars and stopping bleeding in Iran, India and different parts of Caucasia and central Asia (Tada et al., 2002). On the other hand, the aerial parts of both P. pabularia and P. uloptera have high nutritive value and are used in different parts of Iran as an animal fodder. However, the number of wild plants has been declining rapidly due to changing environmental conditions over past decades and excessive harvesting of the wild plants from native fields by horticultural traders, herbalists and husbandries (Razavi and Hajiboland, 2009).
Earlier we studied seed germination and dormancy of $P$. ferulaceae indicate that there is a deep dormancy in the seeds of this plant (Razavi and Hajiboland, 2009). It is obvious that different species of Apiaceae exhibit deep dormancy in seeds that is related to their undeveloped embryos (Baskin and Baskin, 2001).

In order to domesticate and cultivate, we need information on seed germination, dormancy breaking and embryo growth of this plant that are investigated in the present study.

\section{MATERIALS AND METHODS}

Seed materials: Matured seeds of $P$. pabularia and P. uloptera were collected in August 2006 from Siahrood and Mishov dagh in East Azarbaijan province, Iran, respectively. After removal of unwanted materials, the seeds were put into a paper box in the refrigerator at $4^{\circ} \mathrm{C}$ until required. Weight of 1000 seeds was 21 and $28 \mathrm{~g}$ for $P$. pabularia and $P$. uloptera, respectively.

In all treatment, quadruplicate sample of 25 seeds were randomly chosen from seeds. The seeds were sterilized by soaking in $1 \%$ sodium hypochlorite (NaOCL) for $5 \mathrm{~min}$ and subsequently rinsed thoroughly with sterilized water prior to applying any treatment. The seeds were placed on Whatman No.1 filter paper moistened

Corresponding Author: Seyed Mehdi Razavi, Department of Biology, Faculty of Science, University of Mohaghegh Ardabili, Ardabili, Iran 
with $5 \mathrm{~mL}$ of distilled water in sterilized petri dishes (Nadjafi et al., 2006).

Requirements for dormancy break and germination: The following effects were investigated for dormancy breaking and germination.

Effects of different temperatures: In a preliminary experiment, after soaking, the seeds were incubated at 5 , $10,15,20$ and $25^{\circ} \mathrm{C}$ in an incubator for 3 weeks.

Effects of soaking: Seeds were soaked in distilled water for $24 \mathrm{~h}$ and they were placed in an incubator at $25^{\circ} \mathrm{C}$ for 3 week.

Effects of scarification: The pericarp around the seeds was removed with a sterilized scalpel without damaging the embryo. Then, the seeds were kept at $25^{\circ} \mathrm{C}$ for 3 weeks.

Effects of cold stratification and different temperatures: Seeds after being moisturized with distilled water were maintained at a temperature of $5^{\circ} \mathrm{C}$ in an incubator for 8 weeks. Then, in order to determine optimum temperature for germination, the stratified seeds were kept at 2, 5, 10, 15,20 and $25^{\circ} \mathrm{C}$ in an incubator (Walck and Hidayati, 2004).

Effects of duration and temperature of cold stratification: The seeds were separately stratified at 5 and $12^{\circ} \mathrm{C}$ in an incubator for $4,8,12$ and 16 weeks.

Effects of warm stratification: The seeds after being moisturized with distilled water were kept at $30 / 15^{\circ} \mathrm{C}$ in a incubator for 4,8 and 12 weeks.

Effects of alternating low temperatures: After being moisturized with distillated water, the seeds were maintained at $15 / 6^{\circ} \mathrm{C}$ in an incubator for $4,8,12$ and 16 weeks.

Effects of GA3: The seeds were placed on two sheets of Whatman No.1 filter paper and moistened with distilled water or $100,200,500$ and $1000 \mathrm{ppm}\left(\mathrm{mg} \mathrm{mL}^{-1}\right.$ ) of GA3 dissolved in distilled water.

Effects of light and darkness: The seeds stratified at $5^{\circ} \mathrm{C}$ for 8 weeks, were placed in light ( 800 Lux) and darkness for 3 weeks.

After each treatment, except treatment 1, the seeds were transferred to an incubator. with continuous darkness, a constant temperature of $5^{\circ} \mathrm{C}$ for $P$. pabularia and $10^{\circ} \mathrm{C}$ for $P$. uloptera, optimum temperature of germination in each species and a relative humidity between 70 and $75 \%$. Germinated seeds were counted and removed every $24 \mathrm{~h}$ for 3 weeks. A seed was considered germinated when the tip of the radicle had grown free of the seed coat. The germination rate was calculated according to usual method (Zheng et al., 2004).

Embryo morphology and effects of cold stratification on embryo growth: After any treatment, the seeds embryos were excised and were studied morphologically by binuclear. Then, Seeds were placed in an incubator at $5^{\circ} \mathrm{C}$ for $2,4,6,8,10$ and 12 weeks. After each time course, ten seed were chosen and their embryos excised and measured and observed. The seeds were also treated with $100,200,500$ and $1000 \mathrm{mg} \mathrm{mL}^{-1}$ of GA3 for 2 and 6 weeks and their embryos excised and measured (Walck et al., 2002).

Statistical analyses: The means and standard errors were calculated for germination percentages, germination rate and embryo lengths of seedlings. Data from this study was analysis using SPSS 11.5. After conducting an analysis of variance, the Duncan's multiple range test was used to detect significant differences among the treatments with a probability of $95 \%(\mathrm{p}=0.05)$.

\section{RESULTS}

It was described that after stratification, there is a significantly differences $(\mathrm{p} \leq 0.05)$ in seed germination of Prangos species in darkness and light in as much as in $P$. pabularia seed, the germination entirely was inhibited by light (Table 1).

Preliminary tests showed that without any treatment, seed germination was not occurred revealing a kind of deep seed dormancy might exist in the tested species. According to the experiments, in both species, constant temperatures, scarification and soaking of seeds had no effects on seed germination indicating there is no exogenous dormancy in the seeds and the seed dormancy might has endogenous origin.

The obtained results revealed that only stratification at low temperatures promote the germination of $P$. pabularia and $P$. uloptera seeds. The results also indicated that after stratification, the germination percentage and rate were significantly differed at various incubation temperatures $(\mathrm{p} \leq 0.05)$. Whereas, in $P$. pabularia seed, maximum germination occurred at $5^{\circ} \mathrm{C}$, the optimum germination in $P$. uloptera was found to be at $10^{\circ} \mathrm{C}$ (Table 1). It is interesting to note that seed germination in both species was significantly affected $(\mathrm{p} \leq 0.05)$ by stratification temperature and duration. While, maximum seed germination in the both species occurred after 4 weeks of cold stratification at $5^{\circ} \mathrm{C}$, in stratification at $12^{\circ} \mathrm{C}$, maximum percentage and rate of germination occurred after 16 and 12 weeks for $P$. pabularia and $P$. uloptera seeds, respectively (Table 1 ). 
Insight Botany 2 (2): 7-11, 2012

Table 1: Treatments applied for dormancy breaking of tested seeds

\begin{tabular}{|c|c|c|c|c|}
\hline \multirow[b]{2}{*}{ Treatments } & \multicolumn{2}{|l|}{ P. pabularia } & \multicolumn{2}{|l|}{ P. uloptera } \\
\hline & G.R. & G.P & G.R. & G.P. \\
\hline Temprature $\left(5^{\circ} \mathrm{C}\right)$ & 0 & 0 & 0 & 0 \\
\hline Temprature $\left(10^{\circ} \mathrm{C}\right)$ & 0 & 0 & 0 & 0 \\
\hline Temprature $\left(12^{\circ} \mathrm{C}\right)$ & 0 & 0 & 0 & 0 \\
\hline Temprature $\left(15^{\circ} \mathrm{C}\right)$ & 0 & 0 & 0 & 0 \\
\hline Temprature $\left(20^{\circ} \mathrm{C}\right)$ & 0 & 0 & 0 & 0 \\
\hline Temprature $\left(25^{\circ} \mathrm{C}\right)$ & 0 & 0 & 0 & \\
\hline Scarification & 0 & 0 & 0 & 0 \\
\hline Soaking cool water $(72 \mathrm{~h})$ & 0 & 0 & 0 & 0 \\
\hline Stratification $\left(5^{\circ} \mathrm{C}, 8\right.$ weeks $)+2^{\circ} \mathrm{C}$ & $4.2 \pm 0.80^{\mathrm{a}}$ & $30 \pm 1.7^{\mathrm{a}}$ & $1.8 \pm 0.62^{\mathrm{ab}}$ & $10 \pm 1.1^{\mathrm{b}}$ \\
\hline Stratification $\left(5^{\circ} \mathrm{C}, 8\right.$ weeks $)+5^{\circ} \mathrm{C}$ & $4.8 \pm 0.95^{\mathrm{a}}$ & $35 \pm 4.1^{\mathrm{a}}$ & $2.2 \pm 0.2^{\mathrm{ab}}$ & $13 \pm 2.5^{b}$ \\
\hline Stratification $\left(5^{\circ} \mathrm{C}, 8\right.$ weeks $)+10^{\circ} \mathrm{C}$ & $3.3 \pm 0.54^{\mathrm{ab}}$ & $19 \pm 3.1^{\mathrm{b}}$ & $3 \pm 0.30^{b}$ & $21 \pm 0.4_{c}$ \\
\hline Stratification $\left(5^{\circ} \mathrm{C}, 8\right.$ weeks $)+12^{\circ} \mathrm{C}$ & $2.3 \pm 0.51^{\mathrm{bc}}$ & $17 \pm 4.7^{\mathrm{b}}$ & $0.6 \pm 0.28^{\mathrm{ab}}$ & $5 \pm 2.8_{\mathrm{ab}}$ \\
\hline Stratification $\left(5^{\circ} \mathrm{C}, 8\right.$ weeks $)+15^{\circ} \mathrm{C}$ & $3.2 \pm 0.61^{\mathrm{ab}}$ & $17 \pm 2.5^{b}$ & $1.1 \pm 0.71^{\mathrm{ab}}$ & $5 \pm 2.7_{\mathrm{ab}}$ \\
\hline Stratification $\left(5^{\circ} \mathrm{C}, 8\right.$ weeks $)+20^{\circ} \mathrm{C}$ & $0.3 \pm 0.13^{\mathrm{d}}$ & $3 \pm 0.6^{c}$ & $0^{\mathrm{a}}$ & $0^{\mathrm{a}}$ \\
\hline Stratification $\left(5^{\circ} \mathrm{C}, 8\right.$ weeks $)+25^{\circ} \mathrm{C}$ & $1.2 \pm 0.52^{\mathrm{dc}}$ & $8 \pm 2.5^{\mathrm{bc}}$ & $0^{\mathrm{a}}$ & $0^{\mathrm{a}}$ \\
\hline Stratification $\left(5^{\circ} \mathrm{C}, 4\right.$ weeks $)$ & $10.2 \pm 0.59^{a}$ & $51 \pm 2.5^{\mathrm{a}}$ & $5.4 \pm 1.11^{\mathrm{a}}$ & $42 \pm 3.4^{\mathrm{a}}$ \\
\hline Stratification $\left(5^{\circ} \mathrm{C}, 8\right.$ weeks $)$ & $4.8 \pm 0.90^{b}$ & $35 \pm 4.1^{\mathrm{b}}$ & $5.4 \pm 1.20^{\mathrm{a}}$ & $41 \pm 3.4^{\mathrm{a}}$ \\
\hline Stratification $\left(5^{\circ} \mathrm{C}, 12\right.$ weeks $)$ & $3.3 \pm 0.71^{b}$ & $30 \pm 4.0^{b}$ & $4.6 \pm 0.81^{b}$ & $26 \pm 4.2^{b}$ \\
\hline Stratification $\left(5^{\circ} \mathrm{C}, 16\right.$ weeks $)$ & $4.1 \pm 078^{b}$ & $38 \pm 3.8^{\mathrm{ab}}$ & $4.6 \pm 1.01^{b}$ & $12 \pm 1.6^{c}$ \\
\hline Stratification $\left(12^{\circ} \mathrm{C}, 4\right.$ weeks $)$ & $2.6 \pm 0.71^{\mathrm{a}}$ & $43 \pm 1.1^{\mathrm{a}}$ & $0.6 \pm 0.09^{c}$ & $10 \pm 0.9^{a}$ \\
\hline Stratification $\left(12^{\circ} \mathrm{C}, 8\right.$ weeks $)$ & $4.2 \pm 0.19^{\mathrm{ab}}$ & $35 \pm 1.2^{b}$ & $1.8 \pm 0.72^{\mathrm{bc}}$ & $12.5 \pm 2.7^{\mathrm{a}}$ \\
\hline Stratification $\left(12^{\circ} \mathrm{C}, 12\right.$ weeks $)$ & $4.8 \pm 0.80^{b}$ & $40 \pm 2.2^{\mathrm{a}}$ & $4.3 \pm 0.17^{\mathrm{a}}$ & $40 \pm 0.7^{\circ}$ \\
\hline Stratification $\left(12^{\circ} \mathrm{C}, 16\right.$ weeks $)$ & $8.9 \pm 1.28^{\mathrm{ab}}$ & $65 \pm 3.5^{c}$ & $3.2 \pm 0.62^{\mathrm{ab}}$ & $30 \pm 0.7^{\mathrm{ab}}$ \\
\hline Alternating temperatures $\left(15 / 6^{\circ} \mathrm{C}, 4\right.$ weeks $)$ & $1.7 \pm 0.61^{\mathrm{a}}$ & $30 \pm 1.1^{\mathrm{a}}$ & $0.7 \pm 0.03^{\mathrm{a}}$ & $12 \pm 0.5^{\mathrm{a}}$ \\
\hline Alternating temperatures $\left(15 / 6^{\circ} \mathrm{C}, 8\right.$ weeks $)$ & $2.4 \pm .59^{\mathrm{a}}$ & $20 \pm 4.1^{\mathrm{b}}$ & $0.2 \pm 0.01^{b}$ & $2.5 \pm 0.3^{\mathrm{b}}$ \\
\hline Alternating temperatures $\left(15 / 6^{\circ} \mathrm{C}, 12\right.$ weeks $)$ & $1.2 \pm 0.54^{\mathrm{b}}$ & $20 \pm 0.9^{b}$ & $0.1 \pm 0.01^{\mathrm{b}}$ & $2.5 \pm 0.3^{b}$ \\
\hline Alternating temperatures $\left(30 / 15^{\circ} \mathrm{C}, 4\right.$ weeks) & 0 & 0 & 0 & 0 \\
\hline Alternating temperatures $\left(30 / 15^{\circ} \mathrm{C}, 8\right.$ weeks $)$ & 0 & 0 & 0 & 0 \\
\hline Alternating temperatures $\left(30 / 15^{\circ} \mathrm{C}, 12\right.$ weeks) & 0 & 0 & 0 & 0 \\
\hline Stratification $\left(5^{\circ} \mathrm{C}, 8\right.$ weeks $)+$ light & $3.7 \pm 0.04^{\mathrm{a}}$ & $15 \pm 1.3^{\mathrm{a}}$ & $0^{\mathrm{a}}$ & $0^{a}$ \\
\hline Stratification $\left(5^{\circ} \mathrm{C}, 8\right.$ weeks $)+$ darkness & $121.9 \pm 0.20$ & $65 \pm 0.9^{b}$ & $6.6 \pm 0.31^{b}$ & $40 \pm 3.8^{b}$ \\
\hline GA3 (100 ppm, 1 week) & 0 & 0 & $0^{\mathrm{a}}$ & $0^{\mathrm{a}}$ \\
\hline GA3 (500 ppm, 1 week) & 0 & 0 & $0^{\mathrm{a}}$ & $00^{\mathrm{a}}$ \\
\hline GA3 (1000 ppm, 1 week) & 0 & 0 & $0.12 \pm 0.03^{b}$ & $2 \pm 0.12^{b}$ \\
\hline
\end{tabular}

Mean values in the same row followed by the same letter are not signific antly different at the 0.05 level according to the Duncan test

Table 2: Effects of duration of cold stratification $\left(5^{\circ} \mathrm{C}\right)$ on embryo growth of P. pabularia and P. uloptera

\begin{tabular}{|c|c|c|c|c|c|c|c|}
\hline \multirow[b]{2}{*}{ Embry o length (mm) } & \multicolumn{7}{|c|}{ Duration (Weeks) } \\
\hline & 0 & 2 & 4 & 6 & 8 & 10 & 12 \\
\hline P. pabularia & $3.10 \pm 0.3^{\mathrm{a}}$ & $3.35 \pm 0.2^{\mathrm{a}}$ & $5.25 \pm 0.62^{b}$ & $6.84 \pm 0.4^{c}$ & $7.60 \pm 0.4^{\mathrm{d}}$ & $7.84 \pm 0.1^{\mathrm{d}}$ & $7.98 \pm 0.1^{\mathrm{d}}$ \\
\hline P. uloptera & $3.16 \pm 0.1^{\mathrm{a}}$ & $5.05 \pm .05^{b}$ & $5.9 \pm 0.37^{\mathrm{b}}$ & $7.60 \pm 0.73^{c}$ & $7.80 \pm 0.34^{c}$ & $7.90 \pm 0.34^{c}$ & $8.70 \pm 0.40^{\circ}$ \\
\hline
\end{tabular}

Mean values in the same row followed by the same letter are not significantly different at the 0.05 level according to the Duncan test

Table 3: Effects of different concentration of GA3 on embryo growth of P. pabularia and P. uloptera

\begin{tabular}{|c|c|c|c|c|c|c|c|}
\hline \multirow[b]{2}{*}{ Embry o length (mm) } & \multicolumn{7}{|c|}{ Concentration (ppm) } \\
\hline & 0 & 100 & 500 & 1000 & 100 & 500 & 1000 \\
\hline P. pabularia & $3.10 \pm 0.31^{\mathrm{a}}$ & $4.33 \pm 0.20^{b}$ & $4.33 \pm 0.21^{b}$ & $4.60 \pm 0.30^{b}$ & $6.00 \pm 0.80^{c}$ & $6.66 \pm 0.60^{c}$ & $9.30 \pm 0.70^{d}$ \\
\hline P. uloptera & $3.16 \pm 0.16^{\mathrm{a}}$ & $3.93 \pm .06^{\mathrm{a}}$ & $4.53 \pm 0.42^{b}$ & $5.60 \pm 0.37^{\mathrm{c}}$ & $6.50 \pm 0.42^{c}$ & $7.20 \pm 0.34^{\mathrm{d}}$ & $8.70 \pm 0.40^{\mathrm{d}}$ \\
\hline
\end{tabular}

Treatment duration 2-6 weeks. Mean values in the same row followed by the same letter are not significantly different at the 0.05 level according to the Duncan test

The present findings suggested that altering temperatures $\left(15 / 6^{\circ} \mathrm{C}\right)$ had less effective than cold stratifications in breaking the seed dormancy.

It was also described that GA3 and warm stratification could not overcome seed dormancy. However, at high concentration $(1000 \mathrm{ppm})$ GA3 stimulated the radicle emergence of $P$. uloptera seeds only to $2 \%$ of control (Table 1 ).

The results of embryo studies showed that the species of Prangos have linear undeveloped embryos with approximately $3 \mathrm{~mm}$ in length at seed dispersal period that reach to $7-8 \mathrm{~mm}$ during germination (Table 2). The present work showed that embryos length in $P$. pabularia reach from 3.10 to $7.98 \mathrm{~mm}$ during 12 weeks of cold stratification $\left(5^{\circ} \mathrm{C}\right)$. This finding also revealed that in P. uloptera, embryos grew from 3.16 to $8.70 \mathrm{~mm}$ in length during same condition of cold stratification (Fig. 1a,b). This results indicated that GA3 can not substitute the cold stratification for breaking seed dormancy, although it stimulated embryos growth (Table 3). 

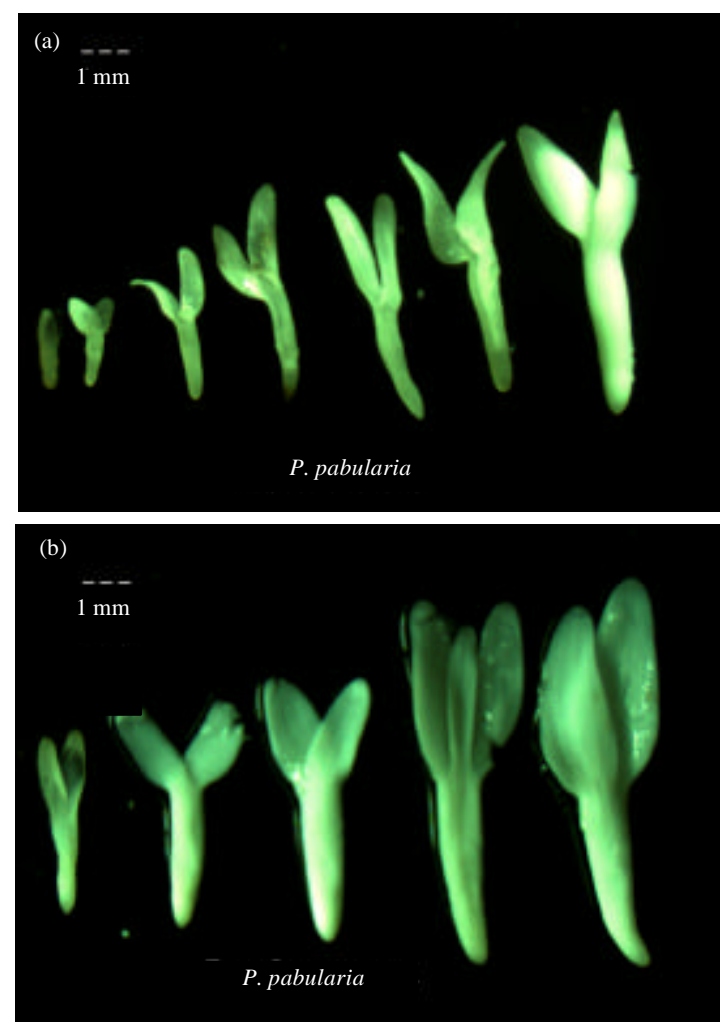

Fig. 1 (a-b): The embryos of P. pabularia and P. uloptera seeds stratified at $5^{\circ} \mathrm{C}$ for different time courses

\section{DISCUSSION}

The results of present work revealed that seeds of $P$. pabularia and $P$. uloptera were dormant at the time of dispersal. The comparison of obtained data with classification of Baskin and Baskin (2001) indicated that the kind of seed dormancy in this plants was Morphophysiological (MPD). This kind of dormancy is related to presence of a undeveloped embryos surrounding by a thick endosperm that prevent from radicle emergence. At low temperatures $\left(<15^{\circ} \mathrm{C}\right)$, endosperm is disrupted to yield nutrients such as glycine and argentine promoting embryos growth. When embryos grow enough to start splitting the endosperm and seed coats, the germination can be occurred (Baskin and Baskin, 2001).

Classification of the type of MPD requires an understanding of conditions necessary for embryos growth. The eight types of MPD are initially divided into two categories, simple and complex, on the basis of temperature at the time of embryo growth. Seeds with simple MPD need relatively high temperatures $\left(>15^{\circ} \mathrm{C}\right)$ for embryo growth whereas those with complex need low temperatures. Further classification of the complex type of MPD into non deep, intermediate or deep depends on the temperature regime required for dormancy break and whether GA3 substitutes for warm or cold stratification. Non deep complex MPD is broken by warm stratification followed by cold stratification, whereas intermediate complex MPD and deep complex MPD are broken only by cold stratification. GA3 substitutes for warm but not cold stratification in seeds with complex MPD and it overcomes dormancy in seeds with intermediate complex MPD but not in seeds with deep complex MPD (Baskin and Baskin, 2001; Walck et al., 2002).

This study demonstrated that seeds of $P$. pabularia and $P$. uloptera have deep complex MPD because cold stratification at $5^{\circ} \mathrm{C}$ broke physiological dormancy and GA3 did not. In both species embryos growth are happen in low temperatures $\left(<12^{\circ} \mathrm{C}\right)$ but germination occur at various temperatures. Optimal germination temperature is determined as $5^{\circ} \mathrm{C}$ for $P$. pabularia and $10^{\circ} \mathrm{C}$ for P. uloptera seeds. Although, GA3 stimulated embryos growth in both species, it could not entirely overcome seed dormancy.

It is also known that seeds of the both species of Prangos exhibit negative photoblasticity and light inhibit seed germination.

MPD has been previously reported from some species of Apiaceae like: Heracleum sphondyllum (Stokes, 1953), Osmorhiza aristata (Walck et al., 2002), Osmorhiza depauperata (Walck and Hidayati, 2004) and Thaspium pinnatifidum (Baskin et al., 1992). It also has been found in some species of Liliaceae and Ranunculaceae (Baskin and Baskin, 2001). In a previous study we also reported that seed dormancy in $P$. ferulaceae was deep complex MPD as well as. We demonstrated that optimal temperature for seed germination of this plant was $15^{\circ} \mathrm{C}$ (Razavi and Hajiboland, 2009). It is well-known that different Prangos species are Iran-Turan elements distributing in semi-arid temperate regions mostly in Turkey, Iran, Caucasia and central Asia (Rechinger and Hedge, 1987). It is thus concluded that seeds of this species are prevented from germination after dispersal in late summer and autumn because they are dormant. Dormancy break in nature take place under the low temperatures of winter and germination occur in late winter and early winter in related to optimal temperature of seed germination in the species. In fact, MPD in some species of temperate regions is a evolutionary mec hanism preventing germination when seedlings would be unlikely to survive. In the other words, it protect seedlings from summer drought and winter cold in semi-arid temperate climate. 


\section{REFERENCES}

Baskin, C.C. and J. Baskin, 2001. Seeds: Ecology, Biogeography and Evolution of Dormancy and Germination. Academic Press, San Diego,.

Baskin, C.C., E.W. Chester and J.M. Baskin, 1992. Deep complex morphophysiological dormancy in seeds of Thaspium pinnatifidum (Apiaceae). Int. J. Plant Sci., 153: 565-571.

Dokoric, D., V.M. Bulatoric, B.D. Bozic, M.V. Kataronovski, T.M. Zrakie and N. Kovacenic, 2004. 3,5-Nonadiyne isolated from the rhizome of Cachrys ferulaceae inhibits endogenous nitric oxide release by rat peritoneal macrophages. Chem. Pharm. Bull., 52: 853-854.

Nadjafi, F., M. Bannayan, L. Tabrizi and M. Rastgoo, 2006. Seed germination and dormancy breaking techniques for Ferula gummosa and Teucrium polium. J. Arid Environ., 64: 542-547.

Razavi, S.M. and R. Hajiboland, 2009. Dormancy breaking and germination of Prangos ferulaceae seeds. Eur. Asian J. BioSci., 3: 78-83.

Rechinger, K.H. and I.C. Hedge, 1987. Flora Iranica. Vol. 162, Akademische Druck and Verlagsanstalt, Graz, Austria.

Shikishima, Y., Y. Takaishi, G. Honda, M. Ito and Y. Takeda et al., 2001. Chemical constituents of Prangos tschimganica: Structure elucidation and absolute configuration of coumarin and furanocoumarin derivatives with anti-HIV activity. Chem. Pharm. Bull., 49: 877-880.
Stokes, P., 1953. The stimulation of growth by low temperature in embryos of Heracleum sphondyllum. J. Exp. Bot., 4: 222-234.

Tada, Y., Y. Shikishima, Y. Takaishi, H. Shibata and T. Higuti et al., 2002. Coumarins and Gamma pyrone derivatives from Prangos pabularia: Antibacterial activity and inhibition of cytokine release. Phytochemistry, 59: 649-654.

Walck, J.L. and S.N. Hidayati, 2004. Germination ecophysiology of the western North American species Osmorhiza depauperata (Apiaceae): Implications of preadaptation and phylogenetic niche conservatism in seed dormancy evolution. Seed Sci. Res., 14: 387-394.

Walck, J.L., S.N. Hidayati and N. Okagami, 2002. Seed germination ecophysiology of the Asian species Osmorhiza aristata (Apiaceae): Comparison with its North American congeners and implications for evolution of types of dormancy. Am. J. Bot, 89: 829-835.

Zheng, Y., Y. Gao, P. An, H. Shimizu and M. Rimmington, 2004. Germination characteristics of Agrophyllum seqarrosum. Can. J. Bot., 82: 1662-1670. 